\title{
Effect of Trichoderma koningiopsis on Chickpea Rhizosphere Activities under Different Fertilization Regimes
}

\author{
Ashmita Tandon, Touseef Fatima, Anshu, Udit Yadav, Suchi Srivastava, \\ Poonam C. Singh*
}

CSIR-National Botanical Research Institute, Lucknow, India

Email: *pc.singh@nbri.res.in, * poonamnbri@gmail.com

How to cite this paper: Tandon, A., Fatima, T., Anshu, Yadav, U., Srivastava, S. and Singh, P.C. (2018) Effect of Trichoderma koningiopsis on Chickpea Rhizosphere Activities under Different Fertilization Regimes. Open Journal of Soil Science, 8, 261-275.

https://doi.org/10.4236/ojss.2018.810020

Received: June 22, 2018

Accepted: October 27, 2018

Published: October 30, 2018

Copyright $\odot 2018$ by authors and Scientific Research Publishing Inc. This work is licensed under the Creative Commons Attribution International License (CC BY 4.0).

http://creativecommons.org/licenses/by/4.0/

\begin{abstract}
Interaction of plant growth promoting microorganisms (PGPMs) with plants involves interplay at physical, physiological and molecular levels. Proliferation and root colonization of PGPMs manipulate the rhizosphere to optimize plant functions. This benefits plant by nutrient enrichment and induction of plant vigor and defense system. The present work aims to decipher the rhizosphere modulations promoted under different fertilization regimes by an organic acid producing Trichoderma koningiopsis strain (NBRI-PR5). Chickpea was selected as the host plant for the study since it responds well to the application of in/organic fertilizers and PGPMs. Microbial communities associated with the rhizosphere were studied by determining culturable population of heterogeneous microflora, and rhizosphere functions were studied by determining the soil enzyme activities and HPLC profiles of organic acids in root exudates. Application of NBRI-PR5 induced changes in rhizosphere in consent with the amendments. The changes observed in microbial populations were found to be associated with the rhizosphere enzymes. The inhibitory effect of chemical fertilizers on rhizosphere microflora was evident from least bacterial CFU observed in the NPK treatments. No detection of alkaline phosphatase enzyme in all the treatments with NBRI-PR5, with organic or inorganic amendments evidently represents the acidified rhizosphere. Similarly, an opposite trend in DHA and protease enzyme activities in the rhizosphere of FYM and FYM+PR5 treated plants showed that NBRI-PR5 had reframed microbial activities to facilitate nutrient uptake in plants rather than fix in the microbes. It is concluded from the study that NBRI-PR5 fatefully modulates rhizosphere activities, specific to different fertilization regimes by varying the enzyme activities to maximize the utilization of available nutrients.
\end{abstract}




\section{Keywords}

Soil Enzymes, Organic Acids, Rhizosphere Remodeling, Integrated Nutrient Management

\section{Introduction}

Unavailable pool of nutrients in soil can be made available to plants in a sustainable way by using beneficial microorganisms. Application of various plant growth promoting microorganisms (PGPMs) are source of nutrients such as nitrogen and phosphorus in plants. All these processes take place in the plant's rhizosphere. The root exudates are widely known to shape the rhizosphere diversity and affect rhizosphere colonization of the bioinoculants [1] [2] [3]. Furthermore, the composition of a plant's exudates depends upon many factors such as its physiological status [4], soil properties [5], fertilization practices [6] and microorganisms [7]. These factors and interactions in turn affect the microbial populations, plant health and productivity. Proliferation of the PGPMs regulates aspects of each other's behavior by manipulating the microbiome to optimize plant functions by reducing disease susceptibility, abiotic stress, and increasing nutrient availability and yields [8] [9].

Chickpea (Cicer arietinum L.) is a prime pulse crop grown widely in the semi-arid regions of India. However, its productivity is low as compared to its potential yield due to imbalance and non availability of nutrition in soils of these regions. Chickpea responds positively with increased yield to application of $\mathrm{P}$ or $P$ solubilizing microbes and other organic and/or inorganic amendments [10] [11]. Therefore, chickpea was selected as the host plant in this study.

Trichoderma, an effective biological control agent for soil borne plant diseases, acts by various antagonistic mechanisms and boosts yield and quality of produce [12] [13] [14]. Trichoderma can grow on different substrates due to its metabolic versatility and therefore, it is easily colonized in rhizosphere of various plants. Many Trichoderma strains acidify their surrounding environment by secreting organic acids and solubilizing phosphates, micronutrients and mineral cations including $\mathrm{K}, \mathrm{Fe}, \mathrm{Mn}$ and $\mathrm{Mg}$ [12] [15]. Soils where these cations are deficient, addition of Trichoderma, results in bio-fertilization by means of metal solubilization increasing crop productivity. Therefore, it is an alternative for reducing usage of chemical fertilizers and pesticides. For this purpose the Trichoderma based formulations is increasingly being applied alone or along with organic or inorganic fertilizers under integrated nutrient management practices [16]. The T. koningiopsis strain NBRI-PR5 (NBRI-PR5) used in this study was selected for its ability to solubilizing $\mathrm{P}$ mediated by organic acids production. The study examined the effects of NBRI-PR5 application when applied in different combinations of different organic and inorganic fertilizers. The effects were observed on overall plant growth promotion, rhizosphere soil microbial 
populations and enzyme activities. We, furthermore, explored the possibility of natural plant-microbiome modulation in presence of NBRI-PR5 to improve plant growth under integrated nutrient management practices. The profile of organic acids in root exudates of the different treatments, differed by the appearance of many small unknown peaks.

\section{Material and Methods}

\subsection{Microorganisms Used and Growth Conditions}

Trichoderma koningiopsis strain NBRI-PR5 (GenBank accession No JN375992) was used as the P solubilizing and organic acid producing strain. NBRI-PR5 was isolated from rice plant collected from fields near Lucknow $\left(26.30^{\circ}\right.$ and $27.10^{\circ} \mathrm{N}$ latitude and $80.30^{\circ}$ and $81.13^{\circ} \mathrm{E}$ longitude). It was selected for the present study after screening of 33 Trichoderma isolates for $\mathrm{P}$ solubilization and biological control of soil borne fungal pathogens (data not given).

\subsection{Organic Acid Production by NBRI-PR5}

Organic acid production by NBRI-PR5 was estimated in modified Trichoderma selective medium (MTSM) derived from TSM [17]) and NBRIP-BPB medium [18]). MTSM contained (per liter): Glucose, 4 g; $\mathrm{MgSO}_{4} \cdot 7 \mathrm{H}_{2} \mathrm{O}, 0.2 \mathrm{~g} ; \mathrm{KCl}, 0.15 \mathrm{~g}$; $\mathrm{NH}_{4} \mathrm{NO}_{3}, 1.0 \mathrm{~g} ; \mathrm{Ca}_{3}\left(\mathrm{PO}_{4}\right)_{2}, 5 \mathrm{~g} ; \mathrm{pH} 6.5 \pm 0.2$. For qualitative studies bromo-phenol blue (BPB) dye, 0.025 was added to the media. NBRI-PR 5 was inoculated in $50 \mathrm{ml}$ MTSM-BPB broth and incubated at $30^{\circ} \mathrm{C}$ on rotary shaker at $150 \mathrm{rpm}$. Change in dye color compared to the un-inoculated control was recorded for ten days. For determination of organic acid production through HPLC, $0.5 \mathrm{ml} \mathrm{NBRI-PR} 5$ spore suspension $\left(10^{6} \mathrm{CFU} / \mathrm{ml}\right)$ was inoculated in $50 \mathrm{ml}$ MTSM broth and incubated at $30^{\circ} \mathrm{C}$ on rotary shaker at $100 \mathrm{rpm}$. The culture filtrate from MTSM after 7th days of Trichoderma growth was used for HPLC analysis of organic acids.

\subsection{Plant Test}

A pot experiment with chickpea was setup in net-house at CSIR-NBRI, Lucknow. Earthen pots, in six replicates were filled with six kg soil and four seeds per pot were sown. Commercially available NPK (20:60:20) was used in two doses, recommended (NPK100\%) and half of the recommended (NPK50\%) [19]. In FYM treatments soil was mixed with FYM in 3:1 ratio (FYM100\%) and 6:1 in FYM50\%. The FYM was commercially procured from a dairy farm. The treatments included 1) un-inoculated control (Cont) 2) NPK100\% 3) NPK50\% 4) FYM100\% 5) FYM50\% 6) NPK50\% + FYM50\% 7) NBRI-PR5 8) NPK100\% + NBRI-PR5 9) NPK50\% + NBRI-PR5 10) FYM100\% + NBRI-PR5 11) FYM50\% + NBRI-PR5 12) NPK50\% + FYM50\% + NBRI-PR5. Seeds of chickpea (variety Radhey) were treated with NBRI-PR5 spore suspension $\left(10^{7} \mathrm{ml}^{-1}\right)$ prepared from 7 day old culture in sterile distilled water (SDW). Soil and microbial parameters were analyzed after 60 days of plant growth (vegetative phase), plant growth and 
yield parameters were taken at seed maturity. For analysis, one plant per replicate was uprooted (total 6 plants/treatment). Soil adhering to the roots from six replicates was pooled for enzyme analysis. Roots, pooled of three replicates, were used for CFU. Other three plant roots were used for extracting root exudates.

\subsection{Soil Microbial Population}

Viable microbes present in the soil samples were determined by standard dilution-plating procedure on selective media [20]. Dilutions of the soil sample were made in sterile saline ( $0.85 \%$ saline) and spread plated in three replicates on various media specific to culture different microbes. After incubation at $28^{\circ} \mathrm{C}$ the microbial colonies were counted for up to 7 days. The number of colony-forming units (cfu) per gram of fresh weight sample was calculated for each sample. Heterogeneous bacteria were quantified on Nutrient agar and actinomycetes on Actinomycetes Isolation Agar media (Hi-media). Total fungi were enumerated on Rose Bengal Agar media (Hi-media) while Trichoderma were enumerated on Trichoderma Selective Media (TSM) [17].

\subsection{Soil Enzymatic Activities}

Enzyme activities were determined in freshly grounded and sieved $(<2 \mathrm{~mm})$ soil samples from rhizosphere region in triplicate. Soil adhering to the up-rooted plants were pooled and divided into three portions and used as replicates for all the parameters. Dehydrogenase activity (DHA) was assayed by the reduction of 2, 3, 5-triphenyl tetrazolium chloride (TTC) and expressed in $\mu \mathrm{g}$ triphenyl formazan (g.sample $)^{-1} \cdot \mathrm{h}^{-1}[21]$. Protease activity (PA) was quantified by determining the amount of amino acids released after incubation of the sample with $\mathrm{Na}$-caseinate for $2 \mathrm{~h}$ at $50^{\circ} \mathrm{C}$ using Folin-Ciocalteau reagent, and the result was expressed in $1 \mathrm{~g}$ tyrosine $(\mathrm{g} \cdot \text { sample })^{-1} \cdot(2 \cdot \mathrm{h})^{-1}[22]$. Alkaline phosphatase and acid phosphatase activity were determined on the basis of released quantity of P-nitrophenol after incubation of sample with pNPG solution for $1 \mathrm{~h}$ at $37^{\circ} \mathrm{C}$ [23]. Colorimetric determination of urease activity was carried out at $690 \mathrm{~nm}$ absorbance following the method of [24].

\subsection{Organic Acid Analysis}

Organic acids were analyzed in the root exudates. The whole plant was uprooted and excess soil was washed using SDW. Root exudates were extracted by placing the intact plant roots in aerated SDW (double distilled) for 6 hours as described by [25]. The extracted exudates from the three plants were pooled and used directly for analyses after passing through $0.2 \mu \mathrm{m}$ filter. The exudates were stored at $-20^{\circ} \mathrm{C}$ until use.

Crude culture filterate of Trichoderma and root exudates were analyzed for the presence of organic acids following [26]. HPLC analyses were conducted by reversed phase chromatography on a $250 \mathrm{~mm} \times 4.6 \mathrm{~mm}$ i.d., $5 \mu \mathrm{m}$ particle C-18 Column, having a UV detector from Cyberlab (Salo Terracce, Millsbury, USA). 
The mobile phase consisted of $25 \mathrm{mM} \mathrm{KH} 2 \mathrm{PO} 4, \mathrm{pH} 2.5$ and methanol (7\%). Flow rate of the mobile phase was $1.0 \mathrm{ml} \cdot \mathrm{min}^{-1}$ and volume injected was $20 \mu \mathrm{l}$. Organic acid standards were obtained from Sigma; solvents were of HPLC grade. Standards used were $100 \mu \mathrm{g} \cdot \mathrm{ml}^{-1}$ of citric, Fumaric, oxalic and tartaric acid; $500 \mu \mathrm{g} \cdot \mathrm{ml}^{-1}$ succinic acid and $1000 \mu \mathrm{g} \cdot \mathrm{ml}^{-1}$ malic acid.

\subsection{Statistical Analysis}

Arithmetic means $( \pm \mathrm{SE})$ of results for each treatment are given throughout the paper. Using SPSS 16.0 (SPSS Inc.) results were compared by performing two way analysis of variance (ANOVA) and Turkey's Test at $\mathrm{P}=0.05$ for plant test and microbial data.

\section{Results}

\subsection{Organic Acids Production}

The organic acid production by NBRI-PR5 was qualitatively indicated in MTSM broth by de-colorization of BPB dye (Figure 1(a)). The HPLC analysis of organic acids produced by NBRI-PR5 was estimated in-vitro using the MTSM after seven days of inoculation. Chromatogram of the organic acid standards is given in Figure 1(b). Figure 1(c) shows the HPLC chromatograms of organic acids produced by NBRI-PR5 under control conditions (MTSM broth with soluble P) and in presence of TCP (insoluble P). Comparison of organic acids standards with the chromatogram of organic acids produced by NBRI-PR5 under in vitro conditions show the enhanced production of acetic acid and malic acid, besides other unidentified compounds in small quantities at RT 4.97, 7.89 and 8.79 min (Figure 1(c)).

\subsection{Plant Test}

A pot experiment with chickpea inoculated by the organic acid producing Trichoderma, NBRI-PR5, was setup with organic and inorganic amendments to study the effects brought about in the rhizosphere due to NBRI-PR5 inoculation.

\subsubsection{Plant Growth Promotion}

The pot experiment shows an overall improvement in the plant growth in presence of NBRI-PR5 irrespective of the organic and inorganic amendments. Effect of NBRI-PR5 application was evident in the plant growth parameters (Table 1). All the treatments inoculated with NBRI-PR5 with or without amendments showed higher root and shoot length $(\sim 11 \%-65 \%$ and $12 \%-48 \%$ respectively) and biomass ( $20 \%$ - 50\% shoot dry weight) as compared to the control. Final harvesting was carried out when more than $70 \%$ of the plants, considering all the treatments were mature. At the time of final harvest NPK100\% and NPK100\% + NBRI-PR5 were in different reproductive stages while plants in all other treatments had reached maturity. Vegetative growth with some flowering was observed in NPK100\% and pod formation stage was observed in NPK100\% + 


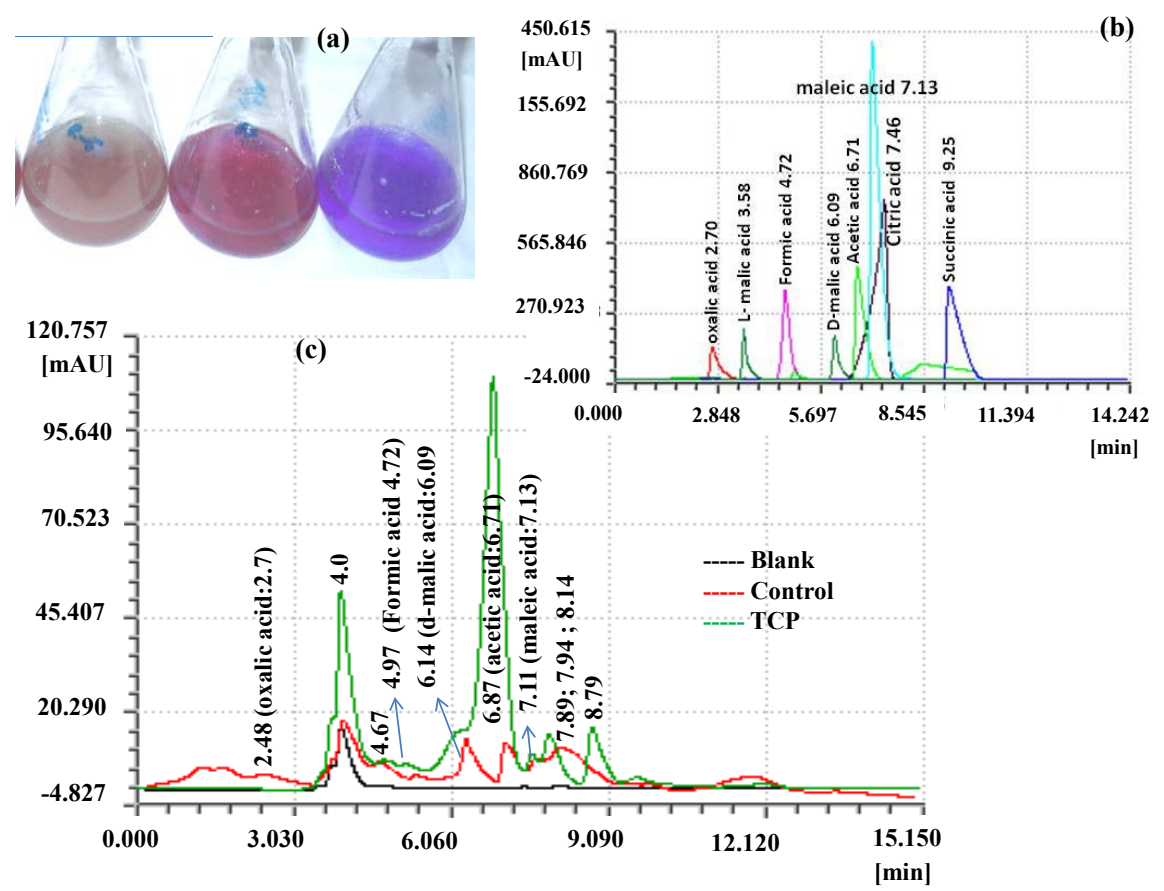

Figure 1. Organic acid production by T. koningiopsis (NBRI-NBRI-PR5) under in-vitro conditions for phosphate solubilization. (a): Discoloration of bromo-phenol dye due to lowering of $\mathrm{pH}$ during qualitative screening of Trichoderma. (b): Chromatograms of the standard organic acids (10 ppm each). (c): Chromatograms of the organic acid profile of Trichoderma in presence of soluble (control) and insoluble (TCP) phosphate.

NBRI-PR5. This was probably due to nutrient enrichment in these treatments, which delayed the maturity.

\subsubsection{Rhizospheric Microbes}

Differences were observed in the heterogeneous population of bacteria, actinomycetes, fungi and Trichoderma in response to NBRI-PR5, NPK and FYM application (Table 2). Application of NPK reduced bacterial and actinomycetes population by $2 \log 10$ units as compared to the control (Table 2). Increased bacterial and actinomycetes population was observed in the NPK50\% dose as compared to the NPK100\%. Colonization of NBRI-PR5 was highest when inoculated with FYM. A decrease in actinomycetes and bacterial population at higher population of Trichoderma (480 CFU. $\mathrm{g}^{-1} \cdot$ soil) indicates changes in the rhizosphere microbial communities in response to different amendments. NBRI-PR5 rhizosphere supported higher counts of bacteria ( $9.0 \log _{10}$ units) and actinomycetes $\left(10.0 \log _{10}\right.$ units). This was probably due to organic acids produced by NBRI-PR5 which overpopulated microbes which are able to use the organic acids, a labile organic carbon source. On the other hand, in the NPK100\% treatment lowering of $\mathrm{pH}$ was not due to organic acids, but due to reaction of the NPK with soil solution. The NPK100\% rhizosphere accumulated inorganic nutrients without organic carbon which affected the growth of indigenous microbial population. The results therefore, show the ability of NBRI-PR5 
Table 1. Plant growth parameters of chickpea plants grown under different regimes of fertilization.

\begin{tabular}{|c|c|c|c|c|c|c|c|c|c|c|}
\hline \multirow{2}{*}{$\begin{array}{l}\text { Sl. } \\
\text { No. }\end{array}$} & \multirow[t]{2}{*}{ Treatments } & \multicolumn{8}{|c|}{ Plant Growth Parameters } & \multirow[b]{2}{*}{ Soil $\mathrm{pH}^{* * *}$} \\
\hline & & $\begin{array}{l}\text { Root length } \\
(\mathrm{cm})\end{array}$ & $\begin{array}{l}\text { Root length } \\
(\mathrm{cm})\end{array}$ & Lateral root no. & Nodule no. & $\begin{array}{c}\text { Root dry } \\
\text { weight }(\mathrm{g})\end{array}$ & $\begin{array}{l}\text { Shoot dry } \\
\text { weight (g) }\end{array}$ & $\begin{array}{c}\text { Seed dry } \\
\text { weight (mg) }\end{array}$ & $S: R^{* *}$ & \\
\hline 1 & Control & $24.3 \pm 0.6^{\mathrm{a}}$ & $13.86 \pm 1.1^{\mathrm{a}}$ & $15.0 \pm 1.21^{\mathrm{ab}}$ & $9.16 \pm 0.87^{\mathrm{a}}$ & $2.46 \pm 0.3^{\mathrm{ab}}$ & $10.93 \pm 1.1 \mathrm{a}$ & Empty pods ${ }^{*}$ & 4.43 & $6.6 \pm 0.4$ \\
\hline 2 & NPK100\% & $34.6 \pm 1.3^{\text {bcde }}$ & $19.0 \pm 0.7^{\mathrm{abc}}$ & $27.5 \pm 2.3^{\text {def }}$ & $12.3 \pm 0.2^{\mathrm{ab}}$ & $2.3 \pm 0.26^{\mathrm{a}}$ & $13.46 \pm 1.0^{\mathrm{abcd}}$ & Vegetative $^{*}$ & 5.86 & $5.6 \pm 0.5$ \\
\hline 4 & FYM100\% & $36.7 \pm 0.6^{\mathrm{de}}$ & $20.36 \pm 0.9^{\mathrm{bc}}$ & $24.3 \pm 0.8^{\text {cdef }}$ & $24.66 \pm 1.41^{\mathrm{d}}$ & $4.33 \pm 0.15^{\mathrm{cd}}$ & $14.16 \pm 0.5^{\mathrm{abcd}}$ & $14.6 \pm 5.1^{\mathrm{e}}$ & 3.27 & $6.7 \pm 0.3$ \\
\hline 5 & FYM50\% & $38.4 \pm 1.0^{\mathrm{e}}$ & $16.16 \pm 0.6^{\mathrm{ab}}$ & $21.8 \pm 1.3^{\text {bcde }}$ & $28.16 \pm 1 . \mathrm{d}^{\mathrm{e}}$ & $4.13 \pm 0.23^{\mathrm{bcd}}$ & $12.96 \pm 0.81^{\mathrm{abc}}$ & $6.5 \pm 3.4^{\mathrm{b}}$ & 3.14 & $6.5 \pm 0.1$ \\
\hline 6 & NPK50\% + FYM50\% & $32.0 \pm 1.8^{\mathrm{bcd}}$ & $18.08 \pm 0.6^{\mathrm{abc}}$ & $29.16 \pm 1.85^{\mathrm{e}}$ & $22.83 \pm 2.6^{\mathrm{cd}}$ & $3.83 \pm 0.43^{\mathrm{abcd}}$ & $11.7 \pm 1.03^{\mathrm{ab}}$ & $8.4 \pm 3.6 b^{c}$ & 3.05 & $6.5 \pm 0.3$ \\
\hline 7 & PR5 & $30.4 \pm 0.8^{\mathrm{b}}$ & $14.86 \pm 0.4^{\mathrm{ab}}$ & $25.6 \pm 0.5^{\text {cdef }}$ & $16.0 \pm 0.52^{\mathrm{abc}}$ & $2.76 \pm 0.2^{\mathrm{abc}}$ & $12.43 \pm 0.3^{\mathrm{abc}}$ & $2.6 \pm 0.96^{\mathrm{a}}$ & 4.49 & $5.9 \pm 0.2$ \\
\hline 9 & NPK50\% + PR5 & $36.1 \pm 1.2^{\text {cde }}$ & $16.96 \pm 1.5^{\mathrm{ab}}$ & $19.5 \pm 1.9^{\mathrm{bc}}$ & $11.166 \pm 1.99^{\mathrm{a}}$ & $3.66 \pm 0.3^{\mathrm{abcd}}$ & $15.73 \pm 0.4^{\mathrm{cd}}$ & $25.8 \pm 4.8^{f}$ & 4.29 & $6.0 \pm 0.1$ \\
\hline 10 & FYM100\% + PR5 & $34.5 \pm 0.9^{\text {bcde }}$ & $20.36 \pm 0.9^{b c}$ & $24.8 \pm 1.08^{\text {cdef }}$ & $39.0 \pm 1.59^{\mathrm{f}}$ & $6.33 \pm 0.43^{e}$ & $13.8 \pm 0.6^{\mathrm{acd}}$ & ${ }^{*} \mathrm{FS}$ & 2.18 & $7.0 \pm 0.3$ \\
\hline 11 & FYM $50 \%$ + PR5 & $35.8 \pm 0.9^{\text {bcde }}$ & $23.33 \pm 2.0^{c}$ & $29.33 \pm 1.20^{f}$ & $33.33 \pm 1.5^{\mathrm{ef}}$ & $5.3 \pm 0.32^{\mathrm{de}}$ & $16.7 \pm 0.74^{\mathrm{d}}$ & $15.6 \pm 5.1^{\mathrm{e}}$ & 3.15 & $6.5 \pm 0.2$ \\
\hline 12 & $\begin{array}{c}\text { NPK50\% + FYM } 50 \% \\
\text { + PR5 }\end{array}$ & $36.2 \pm 1.3^{\text {cde }}$ & $15.41 \pm 1.5^{\mathrm{a}}$ & $20.6 \pm 1.1^{\mathrm{bcd}}$ & $21.83 \pm 1.8^{\mathrm{cd}}$ & $4.36 \pm 0.22^{\mathrm{cd}}$ & $12.1 \pm 0.4^{\mathrm{acd}}$ & $10 \pm 2.7^{\mathrm{cd}}$ & 2.77 & $6.0 \pm 0.3$ \\
\hline
\end{tabular}

${ }^{\star}$ FS: At the time of harvesting these treatments were in different stages of flowering and seed setting stage while others had reached maturity. Results are average of 6 plants per treatment; ${ }^{* *} \mathrm{~S}: \mathrm{R}$ is ratio of shoot and root dry weight; weight; ${ }^{* * *}$ Initial soil pH was $6.7 \pm 0.1$.

Table 2. Heterogeneous populations of cultural microorganisms in chickpea rhizosphere grown under different regimes of fertilization.

\begin{tabular}{|c|c|c|c|c|c|}
\hline \multirow{2}{*}{ S. No. } & \multicolumn{5}{|c|}{ Heterogeneous microbial population $\log _{10} \cdot \mathrm{CFU} \cdot \mathrm{g}^{-1}$} \\
\hline & Treatments & Bacteria & Actinomycetes & Trichoderma & Other Fungi \\
\hline 1 & Control & b $6.71 \pm 0.4$ & ${ }^{\mathrm{d}} 8.56 \pm 0.5$ & ${ }^{\mathrm{ab}} 1.60 \pm 0.3$ & ${ }^{\mathrm{a}} 1.80 \pm 0.4$ \\
\hline 2 & NPK100\% & ${ }^{\mathrm{a}} 4.18 \pm 0.9$ & ${ }^{\mathrm{ab}} 6.92 \pm 0.4$ & ${ }^{\mathrm{ab}} 1.40 \pm 0.2$ & ${ }^{\mathrm{a}} 2.12 \pm 0.3$ \\
\hline 3 & NPK50\% & ${ }^{\mathrm{a}} 5.12 \pm 0.3$ & abc $7.11 \pm 0.8$ & ${ }^{\mathrm{a}} 1.20 \pm 0.2$ & ${ }^{\mathrm{a}} 2.28 \pm 0.5$ \\
\hline 5 & FYM50\% & ${ }^{\mathrm{c}} 6.52 \pm 0.3$ & ${ }^{\mathrm{a}-\mathrm{d}} 7.19 \pm 0.4$ & ${ }^{\mathrm{ab}} 2.16 \pm 0.1$ & ${ }^{\mathrm{a}} 2.28 \pm 0.3$ \\
\hline 6 & NPK50\% + FYM50\% & ${ }^{\mathrm{c}} 6.45 \pm 0.4$ & ${ }^{\mathrm{cd}} 8.24 \pm 0.5$ & ${ }^{b} 2.18 \pm 0.1$ & ${ }^{\mathrm{a}} 2.35 \pm 0.2$ \\
\hline 7 & PR5 & $\mathrm{d}_{9} .13 \pm 0.5$ & ${ }^{\mathrm{e}} 10.60 \pm 0.3$ & ${ }^{b} 2.30 \pm 0.3$ & ${ }^{\mathrm{a}} 2.10 \pm 0.2$ \\
\hline 8 & NPK100\% + PR5 & a $5.36 \pm 0.6$ & ${ }^{\mathrm{a}-\mathrm{d}} 6.72 \pm 0.4$ & ${ }^{b} 2.26 \pm 0.5$ & ${ }^{\mathrm{a}} 2.40 \pm 0.1$ \\
\hline 10 & FYM100\%+ PR5 & ${ }^{\mathrm{bc}} 6.64 \pm 0.5$ & ${ }^{\mathrm{bcd}} 8.16 \pm 0.6$ & ${ }^{b} 2.40 \pm 0.2$ & ${ }^{\mathrm{a}} 2.32 \pm 0.2$ \\
\hline 11 & FYM50\% + PR5 & ${ }^{b c} 5.64 \pm 0.2$ & ${ }^{\mathrm{abcd}} 7.21 \pm 0.5$ & ${ }^{\mathrm{b}} 2.48 \pm 0.8$ & ${ }^{\mathrm{a}} 2.30 \pm 0.4$ \\
\hline 12 & $\mathrm{FYM}+\mathrm{NPK}+\mathrm{PR} 5$ & bc5.68 \pm 0.5 & ${ }^{\mathrm{a}} 6.56 \pm 0.4$ & ${ }^{\mathrm{b}} 2.42 \pm 0.3$ & ${ }^{\mathrm{a}} 2.33 \pm 0.3$ \\
\hline
\end{tabular}

to maintain its population in compliance with the rhizosphere property and also reshape the rhizosphere microbiome differently in different conditions.

\subsubsection{Enzymes in Rhizosphere Soil}

Soil enzymes activity gives information about biological characteristic of the soil. Effect of Trichoderma colonization was assessed on the functional type of soil 
microflora under different fertilizer treatments by examining dehydrogenase (DHA), urease, protease, acid phosphatase and alkaline phosphatase, activities. Contrasting effects of NBRI-PR5 and NPK100\% application were observed on the alkaline and acid phosphatase activities (Figure 2(d), Figure 2(e)). The DHA and protease activities remained unchanged in presence of NBRI-PR5, decreased in presence of NPK $(\sim 50 \%)$ and increased $(>50 \%)$ in presence of organic amendments as compared to control. Bacterial and fungal proteases are important in the recycling of proteins (hydrolysis of $\mathrm{N}$ compounds to NH4), which are induced in response to carbon, nitrogen, or sulphur limitation. Least urease enzyme in the control may be attributed to its low root biomass and absence of organic matter, the enzyme was slightly compensated in the $\mathrm{NPK}_{100 \%}$ and considerably in the NPK50\% treatment (Figure 2), although their microbial populations were less than in other treatments. This shows that source of the enzyme in NPK treatments is additive of microbial origin and of higher root biomass as compared to the control. Two to four fold higher urease activity in FYM50\% + NBRI-PR5 treatment corresponds to its highest root biomass. Therefore, the results indicate shift in source of the enzyme urease depending upon the rhizosphere nutrient composition. Acid phosphatase enzyme was maximum in the treatments NPK100\% and NBRI-PR5 and minimum in NPK50\% and NPK + NBRI-PR5. All the treatments with NBRI-PR5 and NPK100\% did not show the alkaline phosphatase enzyme activity and was recorded to be highest in the control and the FYM treatments. This affirms rhizosphere acidification by NBRI-PR5 as well as NPK resulting in undetectable amounts of alkaline phosphatase enzyme.

\subsubsection{Organic Acids Production in Rhizosphere}

The rhizosphere soils show $\mathrm{pH}$ lowering as compared to the initial bulk soil ( $\mathrm{pH}$ 6.8) used in the experiment (Table 1). Organic acid profile of root exudates, the source of organic acids in rhizosphere from different treatments along with control and standards (oxalic acid and malic acids) is given in Figure 3. Some of the peaks (Figure 3(a), Figure 3(d), black arrows), were found absent from NPK and FYM amendments. The citric acid peak present in the NBRI-PR5 and the NPK100\% treatment was absent from the PR5 + NPK100\% and all the NPK50\% treatments. An unidentified prominent peak at about 12.9 min RT was observed in the FYM50\% + PR5. Malic acid produced in control rhizosphere was maintained in all the treatments without NBRI-PR5, while all the NBRI-PR5 treatments showed decreased malic acid production.

\section{Discussions}

Perturbations due to the agricultural management practices, such as mineral fertilisation or organic matter amendments generally affect the microbial communities and these changes in microbial composition usually prevail over time [27]. Effects of such perturbations on application of the different NPK and FYM doses were observed on the microbial communities. The results show an overall gain in the plant growth/yield in all the NBRI-PR5 treatments as compared to the 

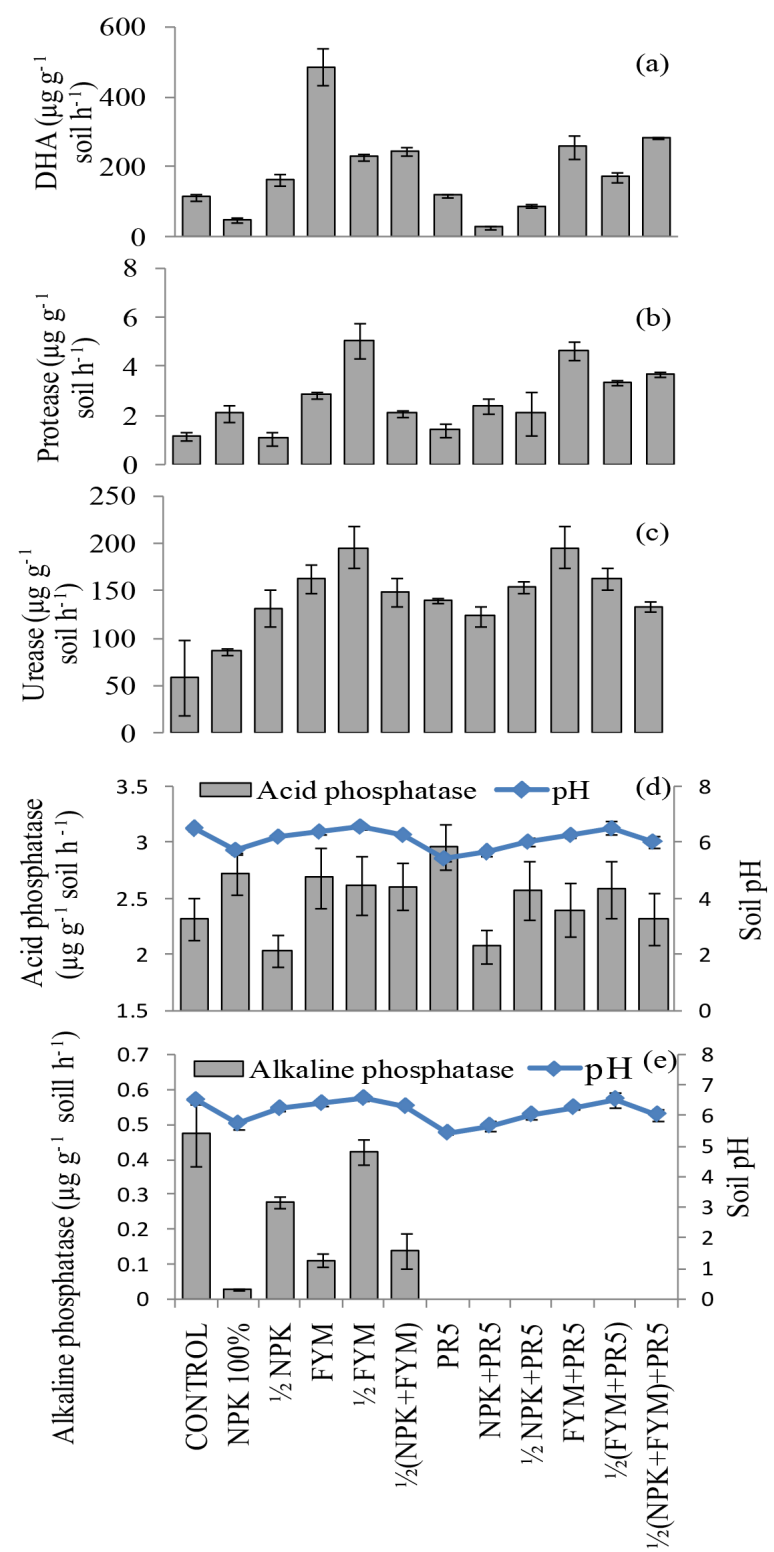

Figure 2. Enzyme activities of rhizosphere soil from chickpea grown under different nutrient management system in presence of T. koningiopsis NBRI-PR5.

corresponding treatments without NBRI-PR5. Based on yield as indicator, the most competent combination appeared to be NBRI-PR5 + NPK50\%, over other amendments. Considering the soil health in terms of microbial activity, FYM treatments were observed to be the best amendments.

Under in-vitro conditions organic acids increased in presence of insoluble $\mathrm{P}$ (TCP) as compared to the control (soluble P), indicating presence of an inducible system for P solubilization. Reference [28] has reported production of organic acids including citric acid, lactic acid and succinic acid by Trichoderma strains under in vitro conditions. The ability of the NBRI-PR5 to produce organic acids was regulatory on the alkaline phosphatase activity and dominance 

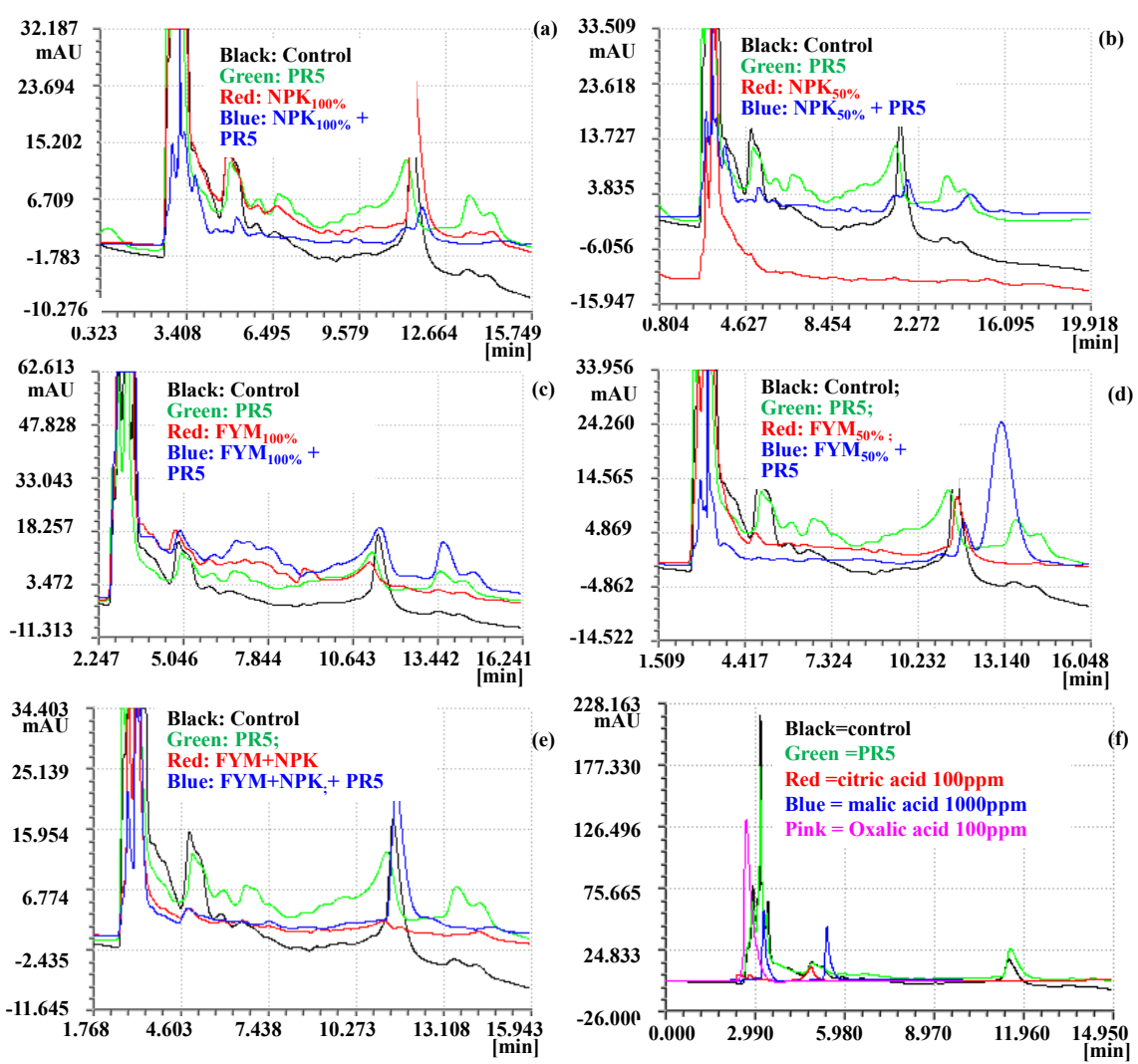

Figure 3. Chromatograms of organic acid profile of root exudates of chickpea plants grown with different organic and inorganic supplements along with P solubilizing Trichoderma (a)-(e); Chromatograms of organic acid standards and organic acid profile of root exudates from control and NBRI-PR5 treated plants (f).

of fungi in the NBRI-PR5 treatments. Reference [29] has reported enhanced production of malic acid, oxalic acid and citric acid in cucumber root exudates in presence of $\mathrm{P}$ solubilizing Trichoderma. The inhibitory effect of chemical fertilizers on rhizosphere microflora was evident from least bacterial CFU observed in the NPK100\% as compared to the NPK50\% and other treatments. NPK has been reported to lower soil $\mathrm{pH}$ in agricultural lands and exert harmful effects [30]. Availability of NPK in NPK100\% treatment showed minimum protease activity due to presence of the nutrients. An increased protease activity in presence of the FYM, with or without NBRI-PR5, shows the need to degrade the organic matter for availability of essential nutrients. Similarly, [31] have reported enhanced protease activity in response to added $\mathrm{C}$ as compared to $\mathrm{N}$.

Being a rhizosphere colonizer Trichoderma are able to influence plants' physiological and biochemical status and affect their rhizosphere [32]. The NBRI-PR5 fatefully modulated rhizosphere activities by inflecting the enzyme activities. Soil microbes, flora and fauna, living or dead are the sources of soil urease [33]; in NPK100\% + PR5 treatment, NBRI-PR5 improved NPK metabolism by increasing the urease activity to yield high root and shoot dry weight as compared to NPK $100 \%$. In treatment NPK50\% + PR5, NBRI-PR5 increased the efficiency of roots in nutrient uptake such that the shoot: root ratio increased 
from 2.88 in NPK50\% to 4.29 in NPK50\% + PR5 giving maximum yield and shoot dry weight. Role and identity of the distinct organic acid peak obtained in the NPK50\% + PR5 treatment may be explored to further decipher the functions of Trichoderma in rhizosphere. In the FYM100\% and FYM100\% + PR5 treatments, opposite trends in DHA and protease enzyme activities show that NBRI-PR5 has reframed microbial activities from assimilative into digestive by increasing protease activity and decreasing DHA activities, to facilitate nutrient uptake in plants rather than fixing in the microbes. Dehydrogenases are intracellular enzymes occurring in all living microbial cells and are therefore, important indicator of overall soil microbial activity [34]. Highest DHA activity in the FYM treatment followed by other treatments with FYM corresponds with the role of DHA in the biological oxidation of soil organic matter by transferring hydrogen from organic substrates to inorganic acceptors under aerobic and anaerobic conditions respectively [35]. The high DHA in presence of FYM suggests presence of anaerobic conditions probably due to formation of anaerobic pockets in the soil by retaining moisture for a longer time [36] [37]. It was observed that while NBRI-PR5 did not disturb the natural DHA activity, it drastically decreased in NBRI-PR5 + NPK100\% indicating unrecoverable role of organic carbon in soil, irrespective of the microbial amendments. In treatments with NPK50\% + FYM50\% and NPK + FYM + PR5 no clear differences were observed in most of the parameters, except an increase in the protease activity with NBRI-PR5. It appeared that application of both NPK and FYM resulted in quenching of NPK by the FYM microflora, reducing the nutrient availability to plants. However, the treatment induced lateral root formation which is supported by earlier report of improved root growth and yield in peanuts using NPK + FYM treatment [38]. The differences in soil enzymes show shift in functions and also composition of the microbial populations. Therefore, the results manifest that the amendments during integrated nutrient management affect the ecology and functions of coherent functional groups formed in the rhizosphere. Reference [39] reported modulation of such coherent rhizosphere PGPRs communities in response to inorganic and organic amendments. Reference [40] highlighted the growing interest to remodel the rhizosphere micro-biome promoting microorganisms that improve plant productivity. Similarly [8] suggested plant microbiome engineering by modulating root exudation, crop rotation, application of microbes secreting signaling compounds such as phyto-hormones, extracellular enzymes, organic acids, plant defense inducing surface factors, antibiotics, volatile signals and quorum sensing molecules and application of organics.

\section{Conclusion}

The study shows the ability of Trichoderma koningiopsis strain NBRI-PR5 to adapt to different rhizosphere conditions by modifying the rhizosphere activities in chickpea to improve plant growth. NBRI-PR5 could induce modulation in the plants rhizospheric enzymes and micro flora to maximize the nutrient use in 
different fertilization regimes. Further deciphering the communication/signaling skills of NBRI-PR5 would provide insight of rhizosphere re-modulation. The Trichoderma koningiopsis isolate NBRI-PR5 may be used with different agricultural practices and crops to improve the availability of nutrients for better crop production.

\section{Acknowledgements}

This study was supported by Projects "Ag-Tech, BSC-011 and RtSF (BSC-0204)" granted from Council of Scientific and Industrial Research, New Delhi, India. AT acknowledges fellowship grant from UGC-CSIR.

\section{Conflicts of Interest}

The authors declare no conflicts of interest regarding the publication of this paper.

\section{References}

[1] Broeckling, C.D., Broz, A.K., Bergelson, J., Manter, D.K. and Vivanco, J.M. (2008) Root Exudates Regulate Soil Fungal Community Composition and Diversity. Applied and Environment Microbiology, 74, 738-744. https://doi.org/10.1128/AEM.02188-07

[2] el Zahar Haichar, F., et al. (2008) Plant Host Habitat and Root Exudates Shape Soil Bacterial Community Structure. The ISME Journal, 2, 1221-1230. https://doi.org/10.1038/ismej.2008.80

[3] McGahan, D.G., Southard, R.J. and Zasoski, R.J. (2014) Rhizosphere Effects on Soil Solution Composition and Mineral Stability. Geoderma, 226, 340-347. https://doi.org/10.1016/j.geoderma.2014.03.011

[4] Chaparro, J.M., Badri, D.V., Bakker, M.G., Sugiyama, A., Manter, D.K. and Vivanco, J.M. (2013) Root Exudation of Phytochemicals in Arabidopsis Follows Specific Patterns That Are Developmentally Programmed and Correlate with Soil Microbial Functions. PloS ONE, 8, e55731. https://doi.org/10.1371/journal.pone.0055731

[5] Neumann, G., Bott, S., Ohler, M., Mock, H.P., Lippmann, R., Grosch, R. and Smalla, K. (2014) Root Exudation and Root Development of Lettuce (Lactuca sativa L. cv. Tizian) as Affected by Different Soils. Frontiers in microbiology, 5, 2 PMCID: PMC3901204. https://doi.org/10.3389/fmicb.2014.00002

[6] Zhu, S., Vivanco, J.M. and Manter, D.K. (2016) Nitrogen Fertilizer Rate Affects Root Exudation, the Rhizosphere Microbiome and Nitrogen-Use-Efficiency of Maize. Applied Soil Ecology, 107, 324-333. https://doi.org/10.1016/j.apsoil.2016.07.009

[7] Kang, B.G., Kim, W.T., Yun, H.S. and Chang, S.C. (2010) Use of Plant GrowthPromoting Rhizobacteria to Control Stress Responses of Plant Roots. Plant Biotechnology Report, 4, 179-183. https://doi.org/10.1007/s11816-010-0136-1

[8] Quiza, L., St-Arnaud, M. and Yergeau, E. (2015) Harnessing Phytomicrobiome Signaling for Rhizosphere Microbiome Engineering. Frontiers in Plant Science, 6, 507. https://doi.org/10.3389/fpls.2015.00507

[9] Smith, D.L., Praslickova, D. and Ilangumaran, G. (2015) Inter-Organismal Signalling and Management of the Phytomicrobiome. Frontiers in Plant Science, 6, 722.

[10] Singh, F. and Diwakar, B. (1995) Chickpea Botany and Production Practices. Skill 
Development Series, 16, 8-9.

[11] Mohammadi, K., Ghalavand, A., Aghaalikhani, M., Heidari, G. and Sohrabi, Y. (2011) Introducing a Sustainable Soil Fertility System for Chickpea (Cicer arietinum L.). African Journal of Biotechnology, 10, 6011-6020.

[12] Harman, G.E., Howell, C.R., Viterbo, A., Chet, I. and Lorito, M. (2004) Trichoderma Species-Opportunistic, Avirulent Plant Symbionts. Nature Review Microbiology, 2, 43-56. https://doi.org/10.1038/nrmicro797

[13] Tripathi, P., Singh, P.C., Mishra, A., Tripathi, R.D. and Nautiyal, C.S. (2015) Trichoderma Inoculation Augments Grain Amino Acids and Mineral Nutrients by Modulating Arsenic Speciation and Accumulation in Chickpea. Ecotoxicology and Environment Safety, 117, 72-80. https://doi.org/10.1016/j.ecoenv.2014.10.027

[14] Bae, S.J., Mohanta, T.K., Chung, J.Y., Ryu, M., Park, G., Shim, S., Hong, S.B., Seo, H., Bae, D.W., Bae, I. and Kim, J.J. (2016) Trichoderma Metabolites as Biological Control Agents against Phytophthora Pathogens. Biological Control, 92, 128-138. https://doi.org/10.1016/j.biocontrol.2015.10.005

[15] Benítez, T., Rincón, A.M., Limón, M.C. and Codón, A.C. (2010) Biocontrol Mechanisms of Trichoderma Strains. International Microbiology, 7, 249-260.

[16] Li, R.X., Cai, F., Pang, G., Shen, Q.R., Li, R. and Chen, W. (2015) Solubilisation of Phosphate and Micronutrients by T. harzianum and Its Relationship with the Promotion of Tomato Plant Growth. PLoS ONE, 10, e0130081.

https://doi.org/10.1371/journal.pone.0130081

[17] Elad, Y. and Chet, I. (1983) Improved Selective Media for Isolation of Trichoderma spp. or Fusarium spp. Phytoparasitica, 1, 55-58. https://doi.org/10.1007/BF02980712

[18] Mehta, S. and Nautiyal, C.S. (2001) An Efficient Method for Qualitative Screening of Phosphate Solubilizing Bacteria. Current Microbiology, 43, 51-56. https://doi.org/10.1007/s002840010259

[19] Tomar, R.K. (2010) Maximization of Productivity for Chickpea through Improved Technologies in Farmer's Fields. Indian Journal of Natural Products and Resources, 4, 515-517. http://nopr.niscair.res.in/handle/123456789/10823

[20] Kumar Srivastava, P., Singh, P.C., Gupta, M., Sinha, A., Vaish, A., Shukla, A., Krishna Tewari, S., et al. (2011) Influence of Earthworm Culture on Fertilization Potential and Biological Activities of Vermicomposts Prepared from Different Plant Wastes. Journal of Plant Nutrition and Soil Science, 174, 420-429. https://doi.org/10.1002/jpln.201000174

[21] Pepper, I.L., Gerba, C.P. and Brendecke, J.W. (1995) Environmental Microbiology: A Laboratory Manual. Academic Press, New York. http://www.microbiologyresearch.org/docserver/fulltext/jmm/46/1/medmicro-46-198a.pdf?expires $=1501154912 \& \mathrm{id}=\mathrm{id} \&$ accname $=$ guest\&checksum $=272 \mathrm{~A} 0 \mathrm{D} 8960048$ F99E0B2151629115FCF

[22] Ladd, J.N. and Butler, J.H. (1972) Short-Term Assays of Soil Proteolytic Enzyme Activities Using Proteins and Dipeptide Derivatives as Substrates. Soil Biology and Biochemistry, 4, 19-30. https://doi.org/10.1016/0038-0717(72)90038-7

[23] Eivazi, F. and Tabatabai, M.A. (1977) Phosphatases in Soils. Soil Biology Biochemistry, 9, 167-172. https://doi.org/10.1016/0038-0717(77)90070-0

[24] Kandeler, E. and Gerber, H. (1988) Short-Term Assay of Soil Urease Activity Using Colorimetric Determination of Ammonium. Biology and Fertility of Soils, 6, 68. https://doi.org/10.1007/BF00257924 
[25] Zang, F., Romhel, V. and Marschner, H. (1991) Release of Zinc Mobilizing Root Exudates in Different Plant Species as Affected by Zinc Nutritional Status. Journal of Plant Nutrition, 14, 675-686. https://doi.org/10.1080/01904169109364234

[26] Cawthray, G.R. (2003) An Improved Reversed-Phase Liquid Chromatographic Method for the Analysis of Low-Molecular Mass Organic Acids in Plant Root Exudates. Journal of Chromatography A, 1011, 233-240. https://doi.org/10.1016/S0021-9673(03)01129-4

[27] Condron, L., Stark, C., O’Callaghan, M., Clinton, P. and Huang, Z. (2010) The Role of Microbial Communities in the Formation and Decomposition of Soil Organic Matter. In: Soil Microbiology and Sustainable Crop Production, Springer, Berlin, 81-118. https://link.springer.com/chapter/10.1007/978-90-481-9479-7_4 https://doi.org/10.1007/978-90-481-9479-7_4

[28] Promwee, A., Issarakraisila, M., Intana, W., Chamswarng, C. and Yenjit, P. (2014) Phosphate Solubilization and Growth Promotion of Rubber Tree (Hevea brasiliensis Muell. Arg.) by Trichoderma Strains. Journal of Agricultural Science, 6, 8. https://doi.org/10.5539/jas.v6n9p8

[29] Zhang, F., Meng, X., Yang, X., Ran, W. and Shen, Q. (2014) Quantification and Role of Organic Acids in Cucumber Root Exudates in Trichoderma harzianum T-E5 Colonization. Plant Physiology and Biochemistry, 83, 250-257. https://doi.org/10.1016/j.plaphy.2014.08.011

[30] Tian, D. and Niu, S. (2015) A Global Analysis of Soil Acidification Caused by Nitrogen Addition. Environmental Research Letters, 10, Article ID: 024019. https://doi.org/10.1088/1748-9326/10/2/024019

[31] Geisseler, D. and Horwath, W.R. (2008) Regulation of Extracellular Protease Activity in Soil in Response to Different Sources and Concentrations of Nitrogen and Carbon. Soil Biology Biochemistry, 40, 3040-3048. https://doi.org/10.1016/j.soilbio.2008.09.001

[32] Cai, F., Chen, W., Wei, Z., Pang, G., Li, R., Ran, W. and Shen, Q. (2015) Colonization of T. harzianum Strain SQR-T037 on Tomato Roots and Its Relationship to Plant Growth, Nutrient Availability and Soil Microflora. Plant and Soil, 388, 337-350. https://doi.org/10.1007/s11104-014-2326-Z

[33] Kumar, S. (2015) Plant Ureases: Physiological Significance, Role in Agriculture and Industrial Applications-A Review. South Asian Journal of Food Technology and Environment, 1, 105-115. http://www.sweft.in/download/volumes1_:_issue_2__/Paper\%201.pdf

[34] Zhao, B., Chen, J., Zhang, J. and Qin, S. (2010) Soil Microbial Biomass and Activity Response to Repeated Drying-Rewetting Cycles along a Soil Fertility Gradient Modified by Long-Term Fertilization Management Practices. Geoderma, 160, 218-224. https://doi.org/10.1016/j.geoderma.2010.09.024

[35] Zhang, N., He, X., Gao, Y., Li, Y., Wang, H., Ma, D., Zhang, R. and Yang, S. (2010) Pedogenic Carbonate and Soil Dehydrogenase Activity in Response to Soil Organic Matter in Artemisia Ordosica Community. Pedosphere, 20, 229-235. https://doi.org/10.1016/S1002-0160(10)60010-0

[36] Brzezińska, M., Stępniewska, Z. and Stępniewski, W. (1998) Soil Oxygen Status and Dehydrogenase Activity. Soil Biology and Biochemistry, 30, 1783-1790. https://doi.org/10.1016/S0038-0717(98)00043-1

[37] Nugroho, S.G., Yoshida, S. and Kuwatsuka, S. (1992) Concurrent Observation of Several Processes of Nitrogen Metabolism in Soil Amended with Organic Materials: Effects of Long-Term Application of Farmyard Manure and Nitrogen Fertilizer on 
N Cycling Processes in Upland Field Soil. Soil Science and Plant Nutrition, 38, 619-629. https://doi.org/10.1080/00380768.1992.10416691

[38] Lalfakzuala, R., Kayang, H. and Dkhar, M.S. (2008) The Effects of Fertilizers on Soil Microbial Components and Chemical Properties under Leguminous Cultivation. American-Eurasian Journal of Agricultural and Environment Science, 3, 314-324.

[39] Liu, Z., Rong, Q., Zhou, W. and Liang, G. (2017) Effects of Inorganic and Organic Amendment on Soil Chemical Properties, Enzyme Activities, Microbial Community and Soil Quality in Yellow Clayey Soil. PLOS ONE, 12, e0172767. https://doi.org/10.1371/journal.pone.0172767

[40] Mendes, R., Garbeva, P. and Raaijmakers, J.M. (2013) The Rhizosphere Microbiome: Significance of Plant Beneficial, Plant Pathogenic, and Human Pathogenic Microorganisms. FEMS Microbiology Reviews, 37, 634-663.

https://doi.org/10.1111/1574-6976.12028 